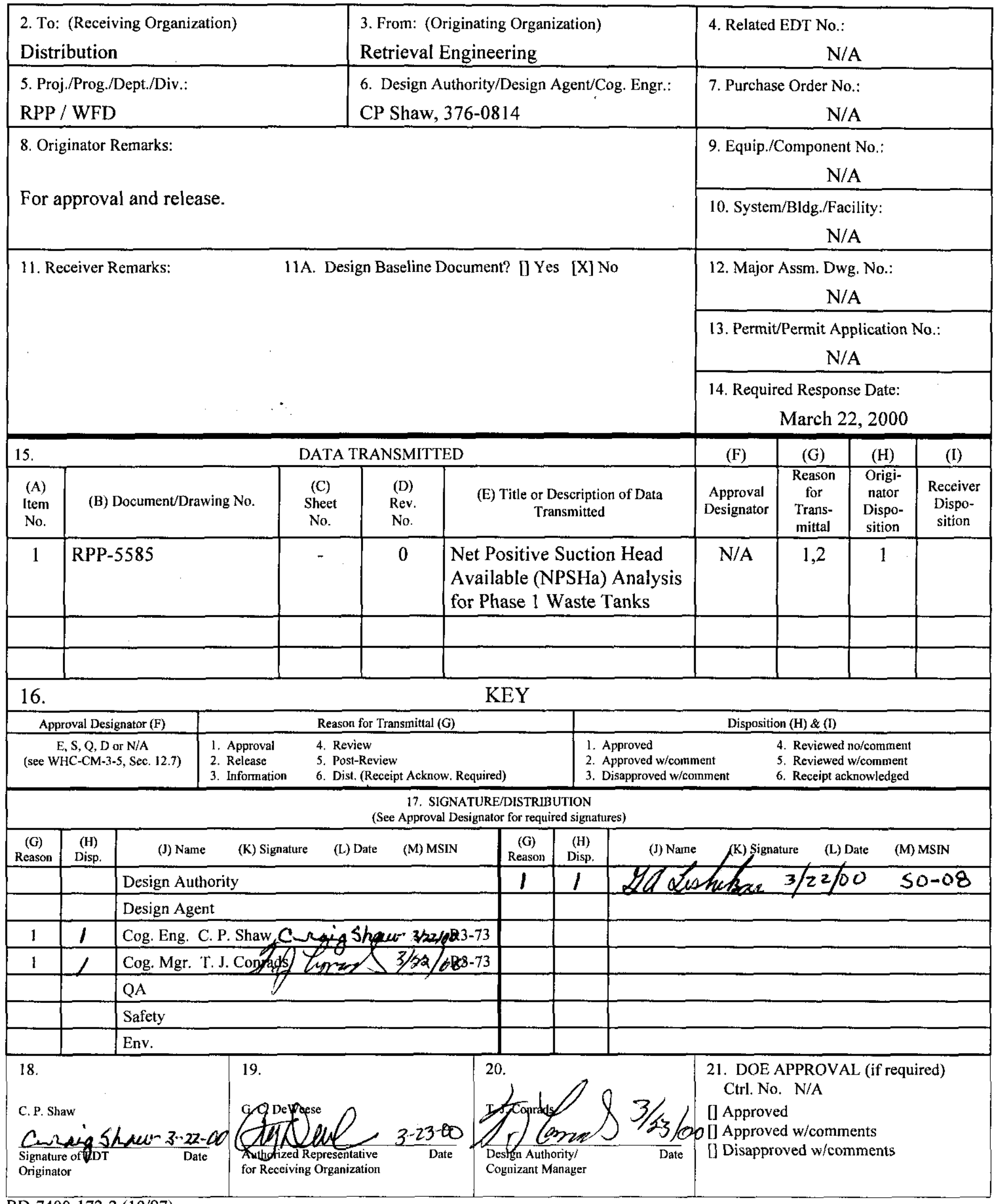


RPP-5585

Revision 0

\section{Net Positive Suction Head Available (NPSHa) Analysis for Phase 1 Waste Tanks}

\section{CH2MHILL Hanford Group, Inc.}

Richland, Washington

Contractor for the U.S. Department of Energy

Office of River Protection under Contract DE-ACO6-99RL14047

Approved for Public Release; Further Dissemination Unlimited 
RPP-5585, Rev. 0

\title{
Net Positive Suction Head Available (NPSHa) Analysis for Phase 1 Waste Tanks
}

\author{
Craig P. Shaw \\ COGEMA Engineering \\ Richland, WA 99352 \\ U.S. Department of Energy Contract DE-AC06-99RL-14047 \\ EDT/ECN: 627143 \\ UC: 721 \\ Org Code: 6 N100 \\ Charge Code: 110300 \\ B\&R Code: \\ Total Pages: 49
}

Key Words: phase 1, double-shell tank, waste feed delivery, net positive suction head

Abstract:

This document identifies the means to determine NPSHa for Hanford waste tanks. It presents the values of vapor pressure and density of Hanford double-shell tank waste as they relate to temperature.

TRADEMARK DISCLAIMER. Reference herein to any specific commercial product, process, or service by trade name, trademark, manufacturer, or otherwise, does not necessarily constitute or imply its endorsement, recommendation, or favoring by the United States Government or any agency thereof or its contractors or subcontractors.

Printed in the United States of America. To obtain copies of this document, contact: Document Control Services, P.O. Box 950, Mailstop H6-08, Richland WA 99352, Phone (509) 372-2420; Fax (509) 376-4989.
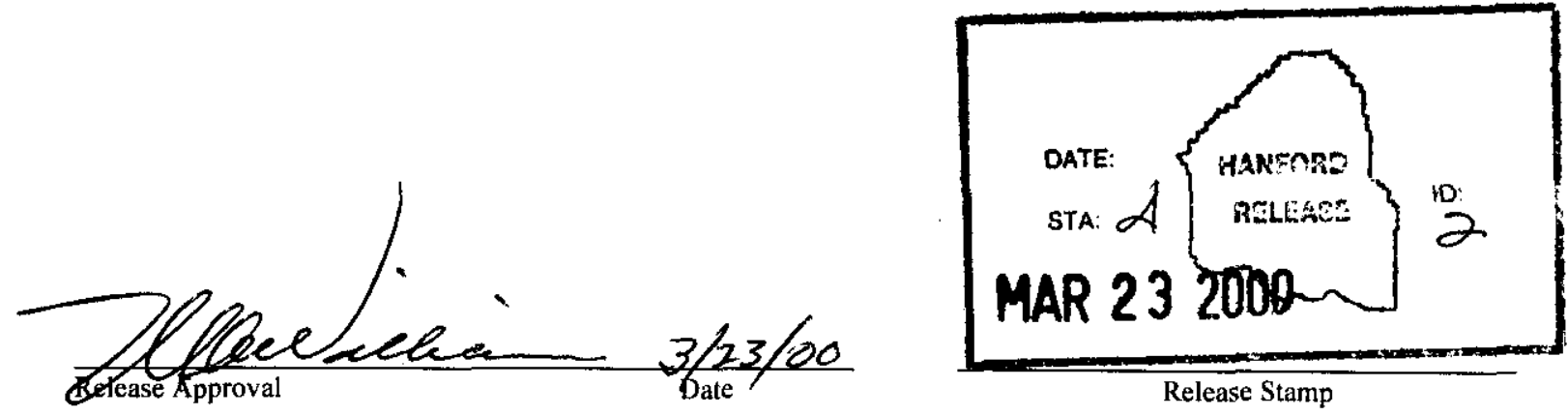

APPROVED FOR PUBLIC RELEASE 


\section{LEGAL DISCLAIMER}

This report was prepared as an account of work sponsored by an agency of the United States Government. Neither the United States Government nor any agency thereof, nor any of their employees, nor any of their contractors, subcontractors or their employees, makes any warranty, express or implied, or assumes any legal liability or responsibility for the accuracy, completeness, or any third party's use or the results of such use of any information, apparatus, product, or process disclosed, or represents that its use would not infringe privately owned rights. Reference herein to any specific commercial product, process, or service by trade name, trademark, manufacturer, or otherwise, does not necessarily constitute or imply its endorsement, recommendation, or favoring by the United States Government or any agency thereof or its contractors or subcontractors. The views and opinions of authors expressed herein do not necessarily state or reflect those of the United States Government or any agency thereof.

This report has been reproduced from the best available copy.

Available in paper copy and microfiche.

Available electronically at http://www.doe.gov/bridge. Available for a processing fee to the U.S. Department of Energy and its contractors, in paper, from:

U.S. Department of Energy

Office of Scientific and Technical Information P.O. Box 62

Oak Ridge, TN 37831-0062

phone: $865-576-8401$

fax: 865-576-5728

email: reports@adonis.osti.gov(423) 576-8401

Available for sale to the public, in paper, from:

U.S. Department of Commerce

National Technical Information Service

5285 Port Royal Road

Springfield, VA 22161

Phone: 800-553-6847

fax: 703-605-6900

email: orders@ ntis.fedworld.gov

online ordering:

http:/www.ntis.gov/ordering.htm 
RPP-5585

Revision 0

\section{Net Positive Suction Head Available (NPSHa) Analysis for Phase 1 Waste Tanks}

C. P. Shaw

COGEMA Engineering Corporation

Date Published

March 2000

Prepared for the U.S. Department of Energy Assistant Secretary for Environmental Management

\section{CH2MHILL \\ Hanford Group, Inc.}

P. O. Box 1500

Richland, Washington

Contractor for the U.S. Department of Energy

Office of River Protection under Contract DE-AC06-99RL 14047

Approved for Public Release; Further Dissemination Unlimited 


\section{CONTENTS}

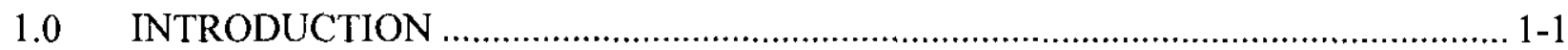

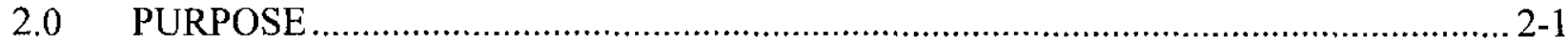

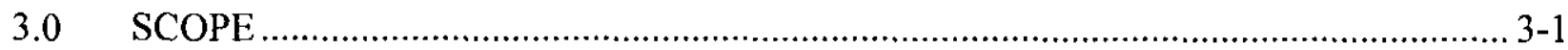

4.0 NET POSITIVE SUCTION HEAD ................................................................. 4-1

4.1 NET POSITIVE SUCTION HEAD EQUATION ........................................ 4-1

4.2 EXAMPLES FOR USING DATA …....................................................... 4-1

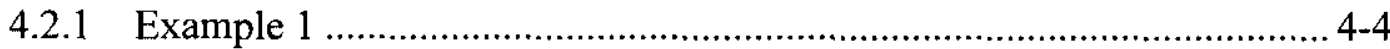

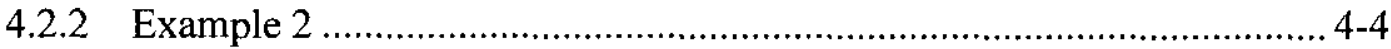

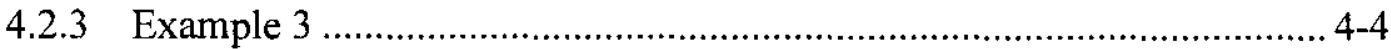

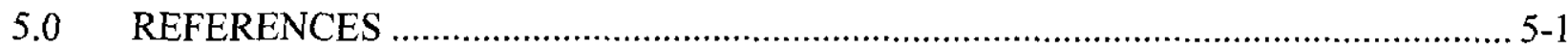

\section{APPENDIX}

A NET POSITIVE SUCTION HEAD AVAILABLE (NPSHa) ANALYSIS FOR PHASE 1 WASTE TANKS.

\section{FIGURES}

Figure 1. High-Level Waste With No Dilution. 4-2

Figure 2. Low-Activity Waste With 1:1 Dilution. 4-3 
RPP-5585 REV 0

\section{TERMS}

HLW

LAW

$\mathrm{NPSH}_{\mathrm{a}}$

$\mathrm{NPSH}_{\mathrm{r}}$ high-level waste

low-activity waste

net positive suction head available

net positive suction head required 


\subsection{INTRODUCTION}

Net positive suction head (NPSH) is a measure of the pressure energy available at the suction eye of a pump impeller. As fluid enters the impeller, it accelerates and its pressure drops, as predicted by the Bernoulli equation. If the fluid pressure drops below the vapor pressure, vapor bubbles form and are carried to a region of higher pressure within the pump, where they violently collapse; this is called cavitation. Cavitation has many effects on a pump. Cavitation will limit the pump's output capacity or liters per second (gallons per minute). The collapse of vapor bubbles erodes the metal from the impeller and also causes the pump to vibrate. Vibration will greatly reduce the life of the pump seals and bearings.

The laws of physics governing the operation of pumps require that the NPSH available $\left(\mathrm{NPSH}_{\mathrm{a}}\right)$ be greater than or equal to the NPSH required $\left(\mathrm{NPSH}_{\mathrm{r}}\right.$ ) to avoid cavitation. Only the pump user can determine $\mathrm{NPSH}_{\mathrm{a}}$, because $\mathrm{NPSH}_{\mathrm{a}}$ is a function of such process system features as hardware architecture, fluid properties, and fluid temperature. The manufacturer determines a pump's $\mathrm{NPSH}_{\mathrm{r}}$, by such features as impeller design and operating radians per second (revolutions per minute). When a pump is procured, the user specifies the discharge pressure, output capacity, and $\mathrm{NPSH}_{\mathrm{a}}$, among other requirements. The manufacturer designs, builds, and tests a pump ensuring that the requirements are satisfied. One of the tests that a manufacturer can perform, if requested, is to determine the onset of cavitation, thereby establishing the $\mathrm{NPSH}_{\mathrm{r}}$. If the $\mathrm{NPSH}_{\mathrm{r}}$ is not less than the $\mathrm{NPSH}_{\mathrm{a}}$, the pump does not meet the user's requirements.

Exact values of $\mathrm{NPSH}_{\mathrm{a}}$, especially in Hanford waste tanks, are subject to uncertainty; therefore some margin must be applied when the user specifies a pump for a specific application. The margin for $\mathrm{NPSH}_{\mathrm{r}}$ can be reduced by having the pump manufacturer conduct a test, as outlined in the Hydraulic Institute Standards, if the first stage impeller is of new design configuration. Even pumps of standard design can have $\mathrm{NPSH}_{\mathrm{r}}$ variations from unit to unit. Reducing uncertainty for $\mathrm{NPSH}_{\mathrm{a}}$ is a function of increased knowledge of waste constituents for specific tanks and the capability to control the waste temperature. 
RPP-5585 REV 0

This page intentionally left blank. 


\subsection{PURPOSE}

A means to determine $\mathrm{NPSH}_{\mathrm{a}}$ for Hanford waste tanks is presented in this document.

Appendix A presents the values of vapor pressure and density of Hanford double-shell tank waste as they relate to temperature. This information is to be used by the projects and design agents to calculate the $\mathrm{NPSH}_{\mathrm{a}}$ for the mixer-pump and transfer-pump detail-design specifications. For a companion document that aids in calculating $\mathrm{NPSH}_{\mathrm{a}}$, see RPP-5637, A Parametric Study to Characterize Alternatives Generation and Analysis Alternatives for Removal of Heat from High-Level Waste Tanks. 
RPP-5585 REV 0

This page intentionally left blank. 


\subsection{SCOPE}

Analysis results of waste vapor pressure and density verses temperature are based on best-basis inventory data from a limited number of tanks (i.e., Tanks 241-AN-102, -103, -104, and -105 for low-activity waste (LAW) and Tank 241-AZ-101 for high-level waste (HLW). These results are presented in Appendix A. The relationships of vapor pressure and density verses temperature change as the waste is diluted with water. Appendix A presents cases for many dilution ratios. If the user of this document determines that the $\mathrm{NPSH}_{\mathrm{a}}$ is marginal when compared to the candidate pump's $\mathrm{NPSH}_{\mathrm{r}}$ for a specific tank pumping application, caution should be used, and it is recommended that a waste analysis be performed for the tank in question with tank-specific waste property data. 
RPP-5585 REV 0

This page intentionally left blank. 


\subsection{NET POSITIVE SUCTION HEAD}

\subsection{NET POSITIVE SUCTION HEAD EQUATION}

$\mathrm{NPSH}_{\mathrm{a}}$ is the total suction head in meters (feet) of liquid absolute, determined at the pump suction nozzles and referenced to a datum, less the absolute vapor of the liquid in meters (feet) of liquid pumped.

Calculation of $\mathrm{NPSH}_{\mathbf{a}}$ is as follows.

$$
\mathrm{NPSH}_{\mathrm{a}}=\frac{g_{c}}{g}\left(\frac{p_{a}-p_{v}}{\rho}-h_{f s}\right) \pm Z_{a}
$$

where

$$
\begin{array}{ll}
g_{c} & =\text { gravitational acceleration of } 9.8 \mathrm{~m} / \mathrm{s}^{2}\left(32.174 \mathrm{ft} / \mathrm{s}^{2}\right) \\
g & =\text { Newton's law proportionality factor of } 9.8 \mathrm{~m} / \mathrm{s}^{2}\left(32.174 \mathrm{ft}-\mathrm{lb} / \mathrm{lb}_{\mathrm{f}}-\mathrm{s}^{2}\right) \\
p_{a} & =\text { absolute pressure at the fluid surface of } 703 \mathrm{~Pa}\left(14.696 \mathrm{lbf} / \mathrm{in}^{2}\right) \\
p_{v} & =\text { vapor pressure of fluid in pascals }\left(\mathrm{lbf} / \mathrm{in}^{2}\right) \\
\rho & =\text { density of fluid in } \mathrm{kg} / \mathrm{m}^{3}\left(\mathrm{lb} / \mathrm{ft}^{3}\right) \\
h_{f s} & =\text { fiction loss in suction line in meters (feet) } \\
Z_{a} & =\text { height of fluid surface above suction in meters (feet). }
\end{array}
$$

For mixer pumps, $\mathrm{h}_{\mathrm{fs}}$ will effectively be zero and $\mathrm{Pa}$ is atmospheric pressure for Hanford tanks; therefore, $\mathrm{NPSH}_{\mathrm{a}}$ is a function of waste depth, temperature, vapor pressure, and density.

For transfer pumps, $\mathrm{h}_{\mathrm{fs}}$ must be calculated for any devices such as a hose that may be ahead of the impeller inlet.

\subsection{EXAMPLES FOR USING DATA}

Figures 1 and 2 illustrate the utility of the data presented in Appendix A. These figures present the relationship of submergence and waste temperature to $\mathrm{NPSH}_{\mathrm{a}}$ for mixer pumps, using two likely waste-dilution scenarios: HLW with no dilution and LAW with 1:1 dilution, respectively. Similar figures can be constructed for other dilutions. Note: Impeller submergence is not the same as tank-waste level, because the impeller inlet is located above the tank bottom. 


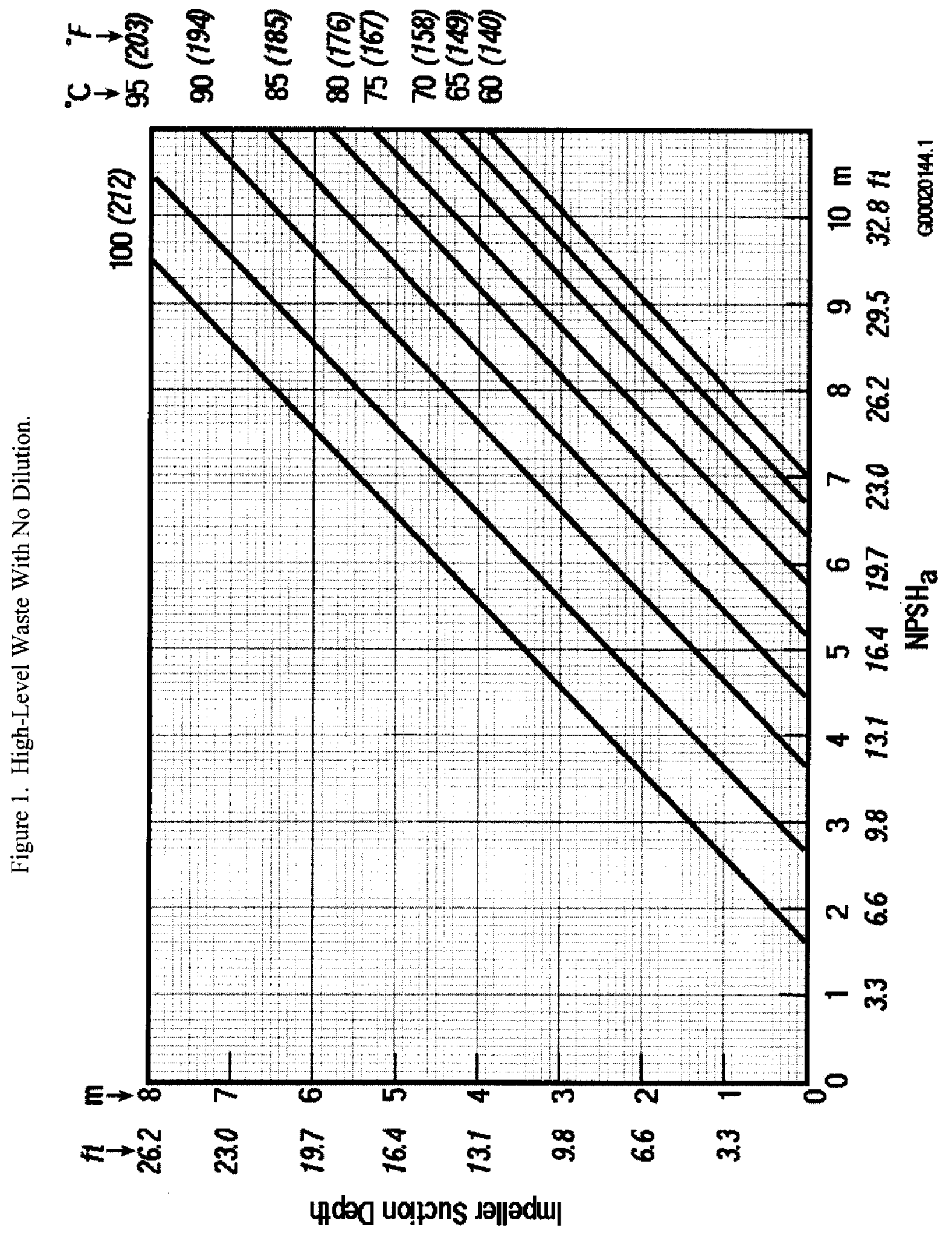


RPP-5585 REV 0

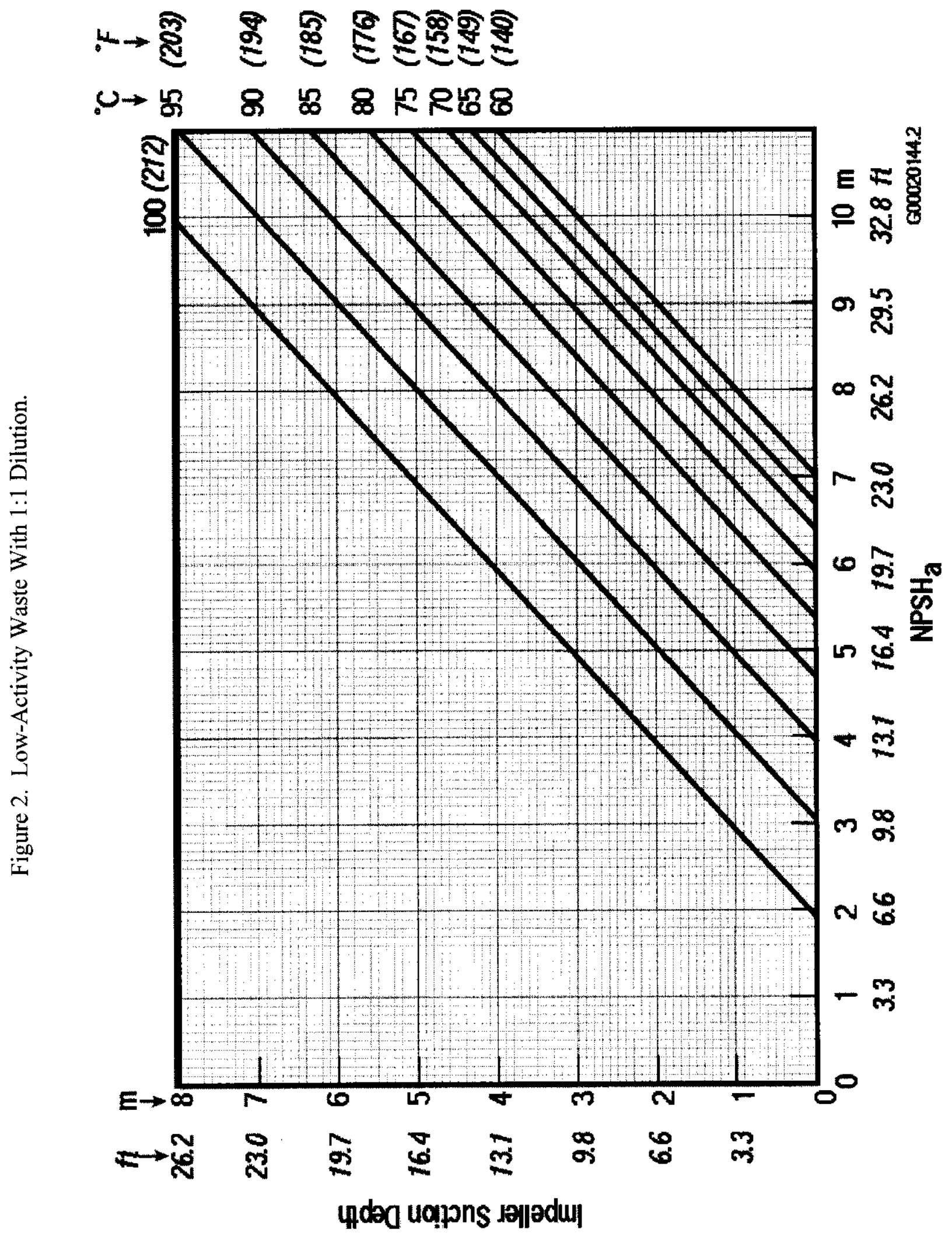




\section{RPP-5585 REV 0}

All of the following examples use Figure 1, High-Level Waste With No Dilution.

\subsubsection{Example 1}

Q: $\quad$ I wish to operate the pump at full power with $2 \mathrm{~m}$ of waste remaining, and I've limited the temperature to $80^{\circ} \mathrm{C}$. What is the $\mathrm{NPSH}_{\mathrm{a}}$ ?

A: Assuming that the impeller is $0.5 \mathrm{~m}$ above the tank bottom, subtract 0.5 from $2.0 \mathrm{~m}$ and read across the $1.5 \mathrm{~m}$ line until it intersects the $80^{\circ} \mathrm{C}$ line. Then read down to $6.7 \mathrm{~m} \mathrm{NPSH}_{\mathrm{a}}$.

\subsubsection{Example 2}

Q: I have a pump with $7.0 \mathrm{~m}$ of $\mathrm{NPSH}_{\mathrm{r}}$ and wish to operate at full power with a $1.5 \mathrm{~m}$ waste level. Assuming that the impeller is $0.5 \mathrm{~m}$ from the tank bottom, what is the maximum waste temperature allowed?

A: Find the intersection of the vertical line of $\mathrm{NPSH}_{\mathbf{a}}=7.0$ and the horizontal line of Submergence $=1.0$. The maximum temperature is approximately $73{ }^{\circ} \mathrm{C}$.

\subsubsection{Example 3}

Q: $\quad$ Can I operate a pump at full power with $\mathrm{NPSH}_{\mathrm{r}}=5.0 \mathrm{~m}$ at the $1.0 \mathrm{~m}$ waste level at $90^{\circ} \mathrm{C}$ ?

A: No, with $0.5 \mathrm{~m}$ impeller submergence at $90^{\circ} \mathrm{C}$, the $\mathrm{NPSH}_{\mathrm{a}}=4.3$. This would not satisfy $\mathrm{NPSH}_{\mathrm{a}}>\mathrm{NPSH}_{\mathrm{r}}$. 


\section{RPP-5585 REV 0}

\subsection{REFERENCES}

Hydraulic Institute Standards, Hydraulic Institute, Cleveland, Ohio.

RPP-5637, 2000, draft, A Parametric Study to Characterize Alternatives Generation and Analysis Alternatives for Removal of Heat from High-Level Waste Tanks, prepared by Numatec Hanford Corporation for CH2M HILL Hanford Group, Inc., Richland, Washington. 
RPP-5585 REV 0

This page intentionally left blank. 
RPP.5585 REV 0

APPENDIX A

NET POSITIVE SUCTION HEAD AVAILABLE (NPSHa) ANALYSIS FOR PHASE 1 WASTE TANKS

\author{
D. J. Geniesse \\ COGEMA Engineering Corporation
}

February 2000

$A-i$ 
RPP-5585 REV 0

This page intentionally left blank.

A-ii 


\section{CONTENTS}

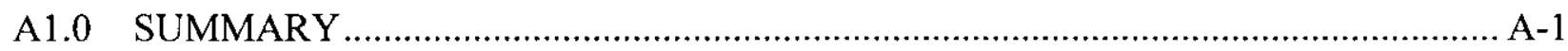

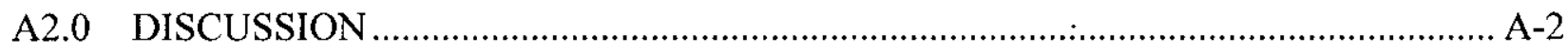

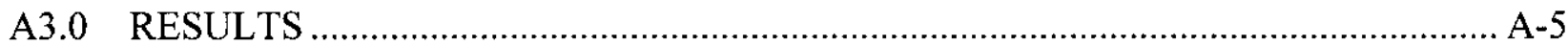

A3.1 EXAMPLE....................................................................................... A-5

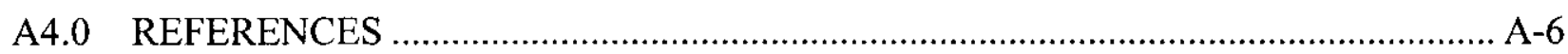

\section{FIGURES}

Figure A1. Low-Activity Waste Vapor Pressure Versus Temperature ................................ A-15

Figure A2. Low-Activity Liquid Density Versus Temperature ....................................... A-16

Figure A3. High-Level Waste Vapor Pressure Versus Temperature ................................. A-17

Figure A4. High-Level Waste Liquid Density Versus Temperature .............................. A-18

\section{TABLES}

Table Ala. Low-Activity Waste Vapor Pressure ......................................................... A-7

Table A1b. Low-Activity Waste Vapor Pressure .................................................... A-8

Table A2a. Low-Activity Waste Liquid Density ........................................................ A-9

Table A2b. Low-Activity Waste Liquid Density ........................................................ A-10

Table A3a. High-Level Waste Vapor Pressure ............................................................... A-11

Table A3b. High-Level Waste Vapor Pressure........................................................... A-12

Table A4a. High-Level Waste Liquid Density ..................................................... A-13

Table A4b. High-Level Waste Liquid Density ........................................................ A-14 


\section{TERMS}

$\begin{array}{ll}\text { BBI } & \text { best-basis inventory } \\ \text { ESP } & \text { Environmental Simulation Program } \\ \text { HLW } & \text { high-level waste } \\ \text { LAW } & \text { low-activity waste } \\ \text { NPSH } & \text { net positive suction head } \\ \mathrm{NPSH}_{a} & \text { net positive suction head available } \\ \mathrm{NPSH}_{r} & \text { net positive suction head required } \\ \text { ORP } & \text { Office of River Protection } \\ \text { RPP } & \text { River Protection Project } \\ \text { WFD } & \text { waste feed delivery }\end{array}$




\section{A1.0 SUMMARY}

The Environmental Simulation Program (ESP) ${ }^{1}$ was used to estimate the liquid properties of low-activity waste (LAW) and high-level waste (HLW). The liquid properties were estimated over temperature and dilution ranges to determine the effects of vapor pressure and liquid density on available net positive suction head $\left(\mathrm{NPSH}_{a}\right)$. Estimates of vapor pressure and liquid density versus temperature and dilution are presented in Tables Ala,b through A4a,b and Figures Al though A4.

$\mathrm{NPSH}_{\mathrm{a}}$ is a measure of the total amount of liquid pressure at the intake of a pump. $\mathrm{NPSH}_{\mathrm{a}}$ must exceed the pump's required net positive suction head $\left(\mathrm{NPSH}_{\mathrm{r}}\right)$ to prevent impeller cavation. $\mathrm{NPSH}_{\mathrm{a}}$ is expressed in meters (feet) of fluid.

The LAW chemistry was estimated from best-basis inventory (BBI) values for Tanks 241-AN-102, -103, -104, and -105. The concentrations of 13 major components were averaged to reduce inaccuracies in inventory data. The HLW chemistry was estimated from the BBI values of Tank 241-AZ-101. The concentrations of 24 compounds were used to increase the accuracy of physical property estimation.

Chemical process modeling is performed using ESP aqueous chemistry software. ESP software is leased from OLI Systems, Inc., of Morris Plains, New Jersey. ESP software is Hanford Siteapproved for simulation of waste-tank chemistry.

The ESP model for the waste-tank system ("GENTANK" chemistry model) is updated continuously to improve accuracy in the thermodynamic prediction of chemical speciation and physical properties. The GENTANK chemistry model used to generate the liquid properties is current as of January 2000.

\footnotetext{
${ }^{1}$ Environmental Simulation Program is a trademark of OLI Systems, Inc.
} 


\section{A2.0 DISCUSSION}

Calculation of $\mathrm{NPSH}_{\mathrm{a}}$ is as follows.

$$
\mathrm{NPSH}_{\mathrm{a}}=\frac{g_{c}}{g}\left(\frac{p_{a}-p_{v}}{\rho}-h_{f s}\right) \pm Z_{a}
$$

where

$$
\begin{aligned}
& g_{c}=\text { gravitational acceleration of } 9.8 \mathrm{~m} / \mathrm{s}^{2}\left(32.174 \mathrm{ft} / \mathrm{s}^{2}\right) \\
& g=\text { Newton's law proportionality factor of } 9.8 \mathrm{~m} / \mathrm{s}^{2}\left(32.174 \mathrm{ft}-\mathrm{lb} / \mathrm{lb}_{\mathrm{r}}-\mathrm{s}^{2}\right) \\
& p_{a}=\text { absolute pressure at the fluid surface of } 703 \mathrm{~Pa}\left(14.696 \mathrm{lbf} / \mathrm{in}^{2}\right) \\
& p_{v}=\text { vapor pressure of fluid in pascals }\left(\mathrm{lb} / \mathrm{in}^{2}\right) \\
& \rho=\text { density of fluid in } \mathrm{kg} / \mathrm{m}^{3}\left(\mathrm{lb} / \mathrm{ft}^{3}\right) \\
& h_{f s}=\text { fiction loss in suction line in meters (feet) } \\
& Z_{a}=\text { height of fluid surface above suction in meters (feet). }
\end{aligned}
$$

In the case where the fluid surface is above the pump impeller (flooded suction), $Z_{a}$ is positive. Where the fluid surface is below the pump suction, $Z_{a}$ is negative.

The LAW chemistry was estimated from BBI values of Tanks 241-AN-102, -103, -104, and -105 . The concentrations of major components were averaged to reduce inaccuracies in inventory data. The BBI values were reconciled for charge and for free hydroxide, then compounded into molecular species. The concentrations of 13 major compounds were averaged for input to ESP molecular species; those concentration averages for Tanks 241-AN-102, -103, -104 , and -105 are as follows.

\begin{tabular}{|l|r|r|r|r|r|}
\hline \multirow{2}{*}{ Compound } & \multicolumn{5}{|c|}{ Tank } \\
\cline { 2 - 6 } & $\begin{array}{c}\text { AN-102 } \\
(\mathrm{g} / \mathrm{L})\end{array}$ & $\begin{array}{c}\text { AN-103 } \\
(\mathrm{g} / \mathrm{L})\end{array}$ & $\begin{array}{c}\text { AN-104 } \\
(\mathrm{g} / \mathrm{L})\end{array}$ & $\begin{array}{c}\text { AN-105 } \\
(\mathrm{g} / \mathrm{L})\end{array}$ & $\begin{array}{c}\text { Average } \\
(\mathrm{g} / \mathrm{L})\end{array}$ \\
\hline $\mathrm{H}_{2} \mathrm{O}$ & 499.40 & 376.50 & 513.56 & 532.68 & 480.53 \\
\hline $\mathrm{Al}(\mathrm{OH})_{3}$ & 44.44 & 179.14 & 107.04 & 105.42 & 109.01 \\
\hline $\mathrm{HCl}$ & 3.85 & 8.19 & 7.96 & 9.81 & 7.45 \\
\hline $\mathrm{Na}_{2} \mathrm{CO}_{3}$ & 120.42 & 45.14 & 98.78 & 81.53 & 86.47 \\
\hline $\mathrm{Cr}(\mathrm{OH})_{3}$ & 0.44 & 1.36 & 2.66 & 1.97 & 1.61 \\
\hline $\mathrm{NaF}$ & 4.01 & 2.17 & 1.40 & 2.22 & 2.45 \\
\hline $\mathrm{KOH}$ & 5.40 & 19.29 & 9.25 & 8.53 & 10.62 \\
\hline $\mathrm{NaOH}$ & 378.70 & 487.86 & 399.20 & 356.76 & 405.63 \\
\hline
\end{tabular}


RPP-5585 REV 0

\begin{tabular}{|l|r|r|r|r|r|}
\hline \multirow{2}{*}{ Compound } & \multicolumn{5}{|c|}{ Tank } \\
\cline { 2 - 6 } & $\begin{array}{c}\text { AN-102 } \\
(\mathrm{g} / \mathrm{L})\end{array}$ & $\begin{array}{c}\mathrm{AN}-103 \\
(\mathrm{~g} / \mathrm{L})\end{array}$ & $\begin{array}{c}\mathrm{AN}-104 \\
(\mathrm{~g} / \mathrm{L})\end{array}$ & $\begin{array}{c}\text { AN-105 } \\
(\mathrm{g} / \mathrm{L})\end{array}$ & $\begin{array}{c}\text { Average } \\
(\mathrm{g} / \mathrm{L})\end{array}$ \\
\hline $\mathrm{HNO}_{2}$ & 82.41 & 140.49 & 95.04 & 120.62 & 109.64 \\
\hline $\mathrm{HNO}_{3}$ & 223.76 & 204.38 & 143.29 & 173.38 & 186.20 \\
\hline $\mathrm{Na}_{3} \mathrm{PO}_{4} \cdot 0.25 \mathrm{NaOH}$ & 8.77 & 4.57 & 8.11 & 8.71 & 7.54 \\
\hline $\mathrm{Na}_{3} \mathrm{H}_{\left(\mathrm{SO}_{4}\right)_{2}}$ & 21.64 & 4.30 & 13.07 & 7.30 & 11.58 \\
\hline Acetic Acid & 62.15 & 5.81 & 6.41 & 17.58 & 22.99 \\
\hline Oxalic Acid & 49.08 & 2.18 & 9.60 & 0.00 & 15.21 \\
\hline Total & $1,507.34$ & $1,483.53$ & $1,417.81$ & $1,426.49$ & $1,456.94$ \\
\hline
\end{tabular}

The HLW chemistry was estimated from Tank 241-AZ-101 BBI. Values were reconciled for charge and for free hydroxide, then compounded into molecular species. The concentrations of 24 major compounds are as follows.

\begin{tabular}{|l|r|}
\hline \multicolumn{1}{|c|}{ Compound } & $\mathrm{g} / \mathrm{L}$ \\
\hline $\mathrm{Al}(\mathrm{OH})_{3}$ & 39.02 \\
\hline $\mathrm{Bi}(\mathrm{OH})_{3}$ & 0.01 \\
\hline $\mathrm{Ca}(\mathrm{OH})_{2}$ & 0.29 \\
\hline $\mathrm{HCl}$ & 0.18 \\
\hline $\mathrm{Na}_{2} \mathrm{CO}_{3}$ & 52.10 \\
\hline $\mathrm{Cr}(\mathrm{OH})_{3}$ & 0.17 \\
\hline $\left.\mathrm{H}_{2}(\mathrm{CrO})_{4}\right)$ & 1.45 \\
\hline $\mathrm{CsOH}$ & 0.08 \\
\hline $\mathrm{NaF}$ & 3.69 \\
\hline $\mathrm{Fe}(\mathrm{OH})_{3}$ & 12.34 \\
\hline $\mathrm{KOH}$ & 6.21 \\
\hline $\mathrm{La}(\mathrm{OH})_{3}$ & 0.33 \\
\hline $\mathrm{NaOH}$ & 134.34 \\
\hline $\mathrm{Ni}(\mathrm{OH})_{2}$ & 0.59 \\
\hline $\mathrm{HNO}$ & 58.76 \\
\hline
\end{tabular}


RPP-5585 REV 0

\begin{tabular}{|l|c|}
\hline \multicolumn{1}{|c|}{ Compound } & $\mathrm{g} / \mathrm{L}$ \\
\hline $\mathrm{HNO}_{3}$ & 67.58 \\
\hline $\mathrm{Pb}(\mathrm{OH})_{2}$ & 0.15 \\
\hline $\mathrm{Na}_{3} \mathrm{PO}_{4} \cdot 0.25 \mathrm{NaOH}$ & 2.38 \\
\hline $\mathrm{Pu}(\mathrm{OH})_{4}$ & 0.01 \\
\hline $\mathrm{SiO}_{2}$ & 0.81 \\
\hline $\mathrm{Na}_{3} \mathrm{H}\left(\mathrm{SO}_{4}\right)_{2}$ & 21.61 \\
\hline $\mathrm{Sr}(\mathrm{OH})_{2}$ & 0.04 \\
\hline Acetic Acid & 1.31 \\
\hline Oxalic Acid & 1.96 \\
\hline Total & 405.45 \\
\hline
\end{tabular}




\section{A3.0 RESULTS}

The ESP-estimated liquid physical properties for LAW and HLW are as follows.

\begin{tabular}{|l|c|c|}
\hline \multicolumn{1}{|c|}{ Liquid Properties } & $\begin{array}{c}\text { Low-Activity } \\
\text { Waste }\end{array}$ & High-Level Waste \\
\hline Temperature $\left({ }^{\circ} \mathrm{C}\right)$ & 40 & 40 \\
\hline $\mathrm{pH}$ & 15.3 & 13.9 \\
\hline Vapor pressure, $\mathrm{Pa}\left(\mathrm{lbf} / \mathrm{in}^{2}\right.$ absolute) & 0.486 & 0.855 \\
\hline Boiling point $\left({ }^{\circ} \mathrm{C}\right)$ & 121.0 & 106.7 \\
\hline Solids fraction $(\mathrm{wt} \%)$ & 0.068 & 0.046 \\
\hline Liquid density $\left(\mathrm{g} / \mathrm{cm}^{3}\right)$ & 1.457 & 1.264 \\
\hline Solid density $\left(\mathrm{g} / \mathrm{cm}^{3}\right)$ & 2.514 & 3.331 \\
\hline Electrical conductivity $(1 / \Omega$-cm) & 0.31 & 0.31 \\
\hline Viscosity, Pa $\cdot \mathrm{s}(\mathrm{cP})$ & 7.86 & 2.59 \\
\hline Ionic strength $(\mathrm{molality})$ & 18.43 & 8.04 \\
\hline
\end{tabular}

Liquid properties were estimated over a temperature range from 5 to $120^{\circ} \mathrm{C}$ and dilution ranges from 0 to 16 volumes of water per volume of original solution $\left(\mathrm{V}_{\mathrm{w}} / \mathrm{V}_{\mathrm{o}}\right)$. Vapor-pressure and liquid-density data are shown in Tables Ala,b through A4a,b.

\section{A3.1 EXAMPLE}

Determine the NPSH available for LAW with $1: 1$ water to waste dilution $\left(\mathrm{V}_{\mathrm{w}} / \mathrm{V}_{\mathrm{o}}\right)$ at $50^{\circ} \mathrm{C}$ with the pump impeller $3.66 \mathrm{~m}(12 \mathrm{ft})$ below the fluid surface.

From Table $1 \mathrm{a}, \mathrm{LAW}$ vapor pressure $\left(\mathrm{p}_{\mathrm{v}}\right)$ at $1: 1$ dilution and $50^{\circ} \mathrm{C}=1.378 \mathrm{lbf} / \mathrm{in}^{2}$.

From Table $2 \mathrm{a}$, LAW liquid density $(\rho)$ at $1: 1$ dilution and $50^{\circ} \mathrm{C}=78.16 \mathrm{lb} / \mathrm{ft}^{3}$.

At 12 feet of submergence,

$$
\mathrm{NPSH}_{\mathrm{a}}=\frac{g_{c}}{g}\left(\frac{p_{a}-p_{\nu}}{\rho}-h_{f s}\right) \pm Z_{a} .
$$


Assume:

$$
\begin{aligned}
\mathrm{g}_{\mathrm{c}} / \mathrm{g}= & 1.0 \mathrm{lbf} / \mathrm{lb} \\
p_{a}= & 14.696 \mathrm{lbf} / \mathrm{in}^{2} \\
h_{f s}= & 0 \mathrm{ft} . \\
& \quad \mathrm{NPSHa}=1\left(\frac{(14.696-1.378)\left(12^{2}\right)}{78.16}-0\right)+12=36.5 \mathrm{ft} \\
& =11.1 \mathrm{~m} .
\end{aligned}
$$

\section{A4.0 BIBLIOGRAPHY}

1. W. L. McCabe, J. C. Smith, and P. Harriott, 1993, Unit Operations of Chemical Engineering, Fifth Edition, McGraw-Hill, New York, New York, pp. 191-193. 
İ I

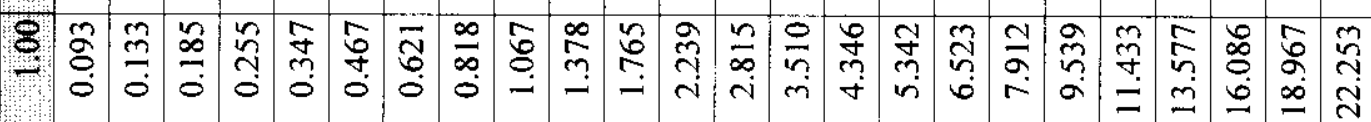

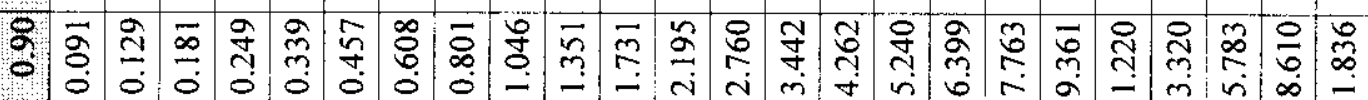
: 00000000 i

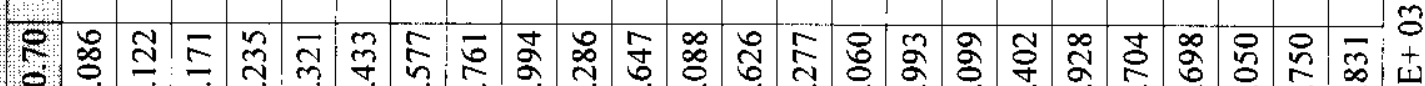

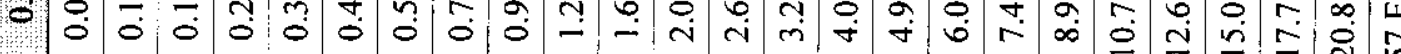

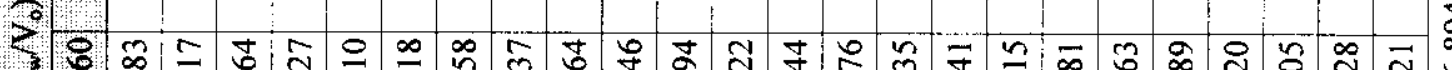

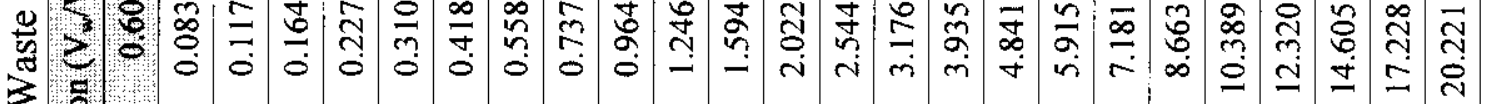

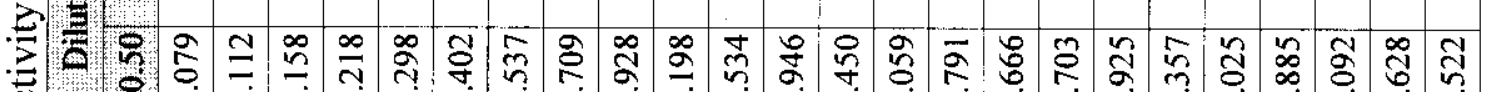

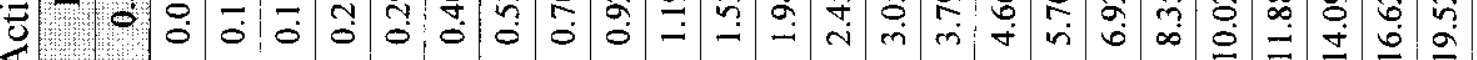

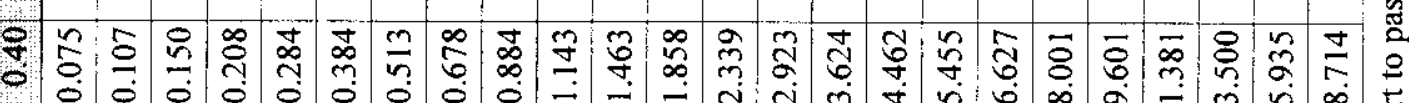

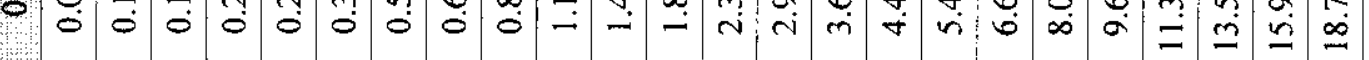

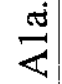

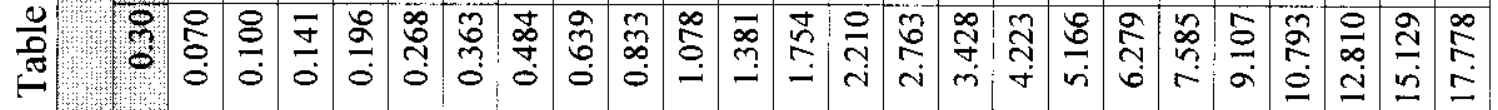

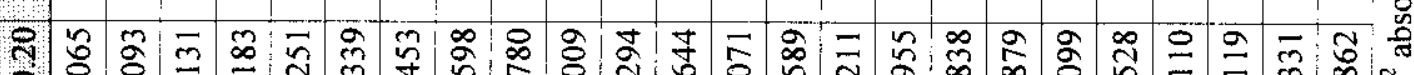

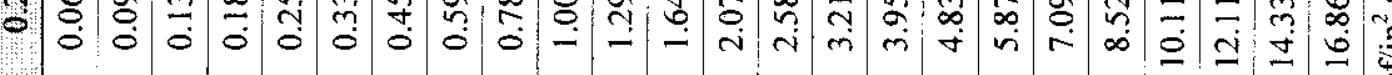
융 0

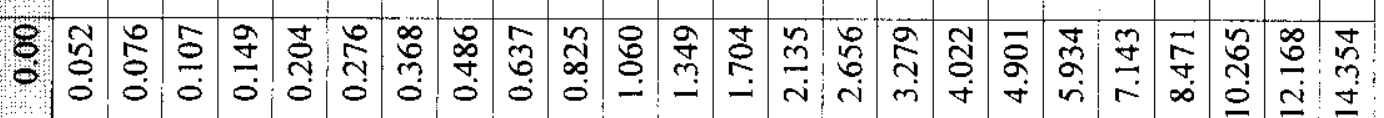
응 


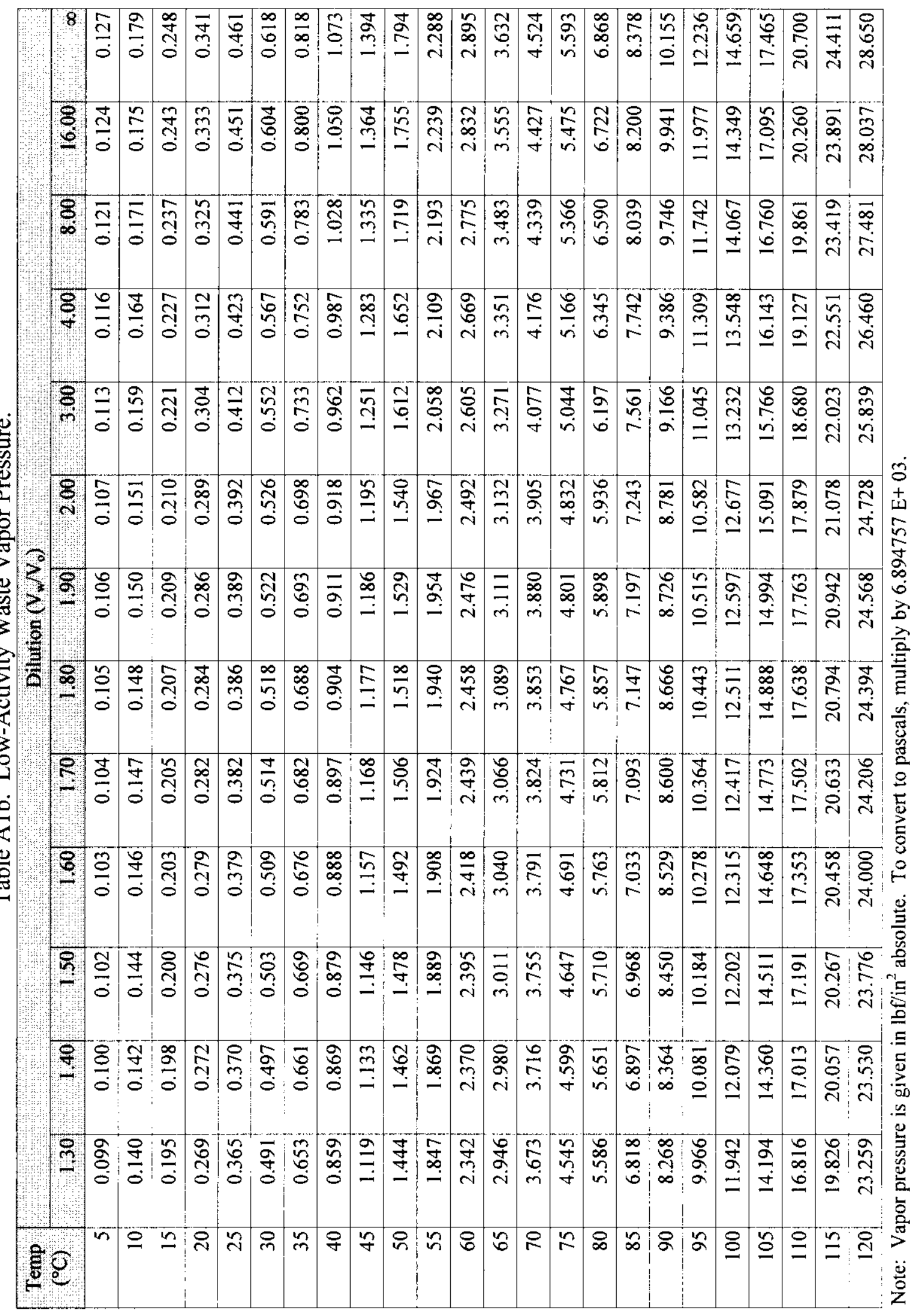




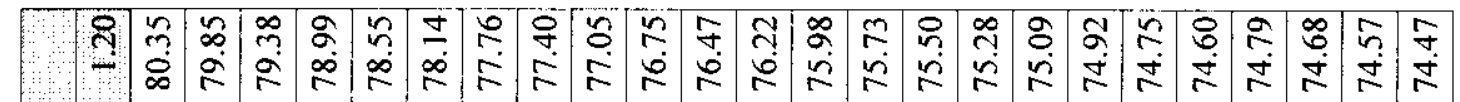

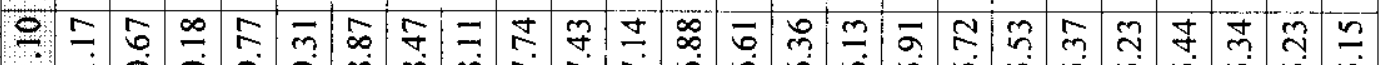

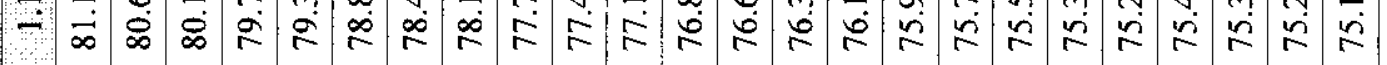

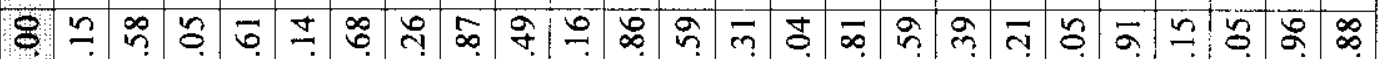
-

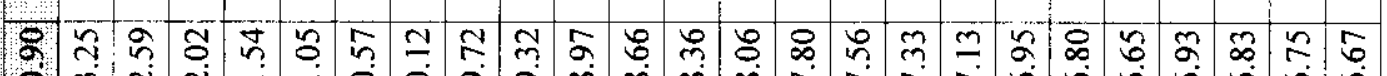

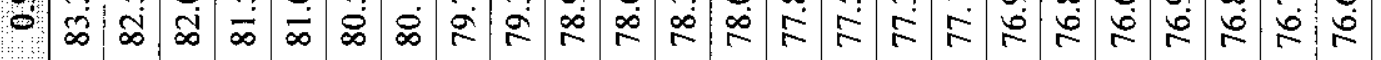

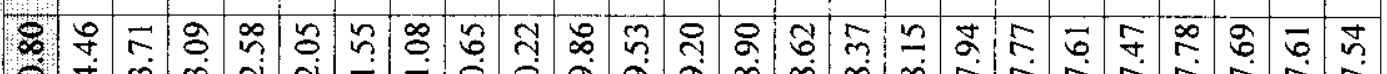

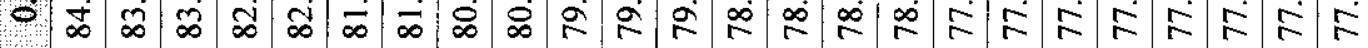

Rำ ठவ

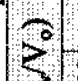

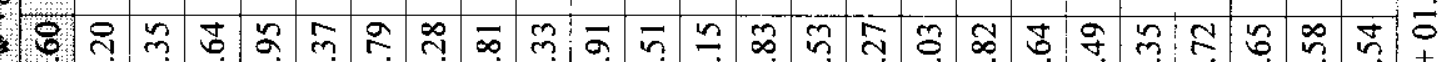

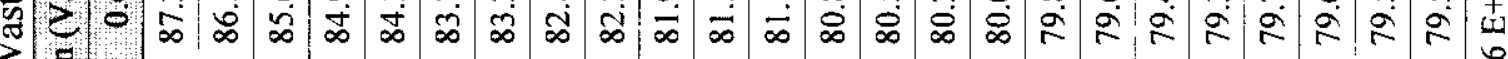

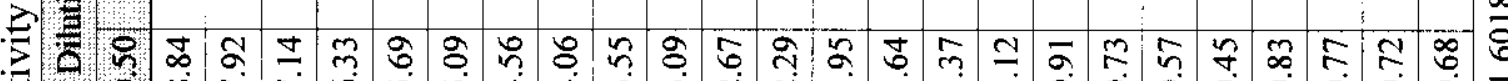

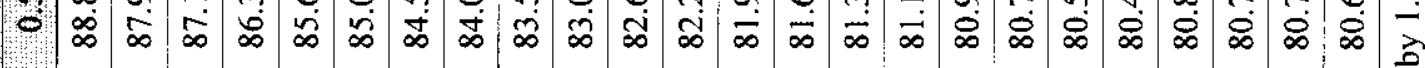

+

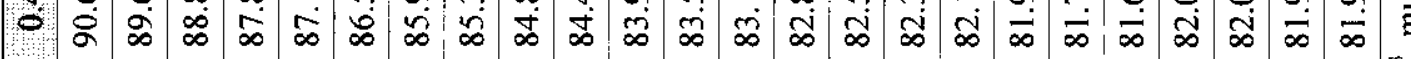

கิ 0 人

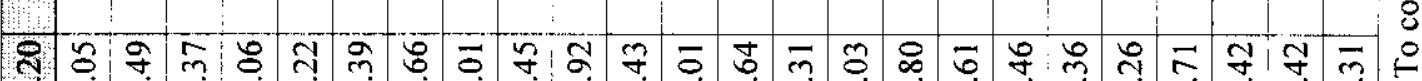
-

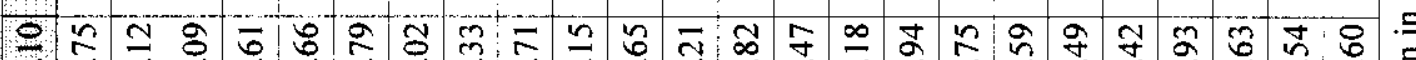

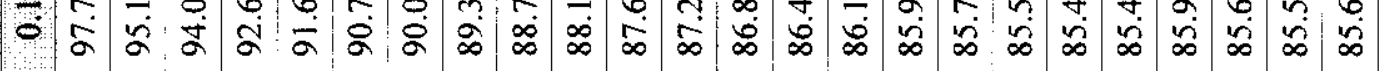
8요

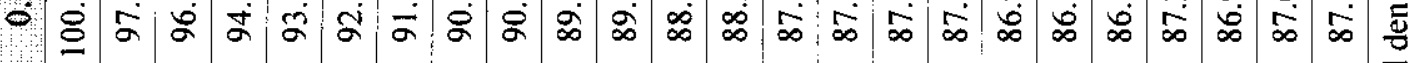
है? 


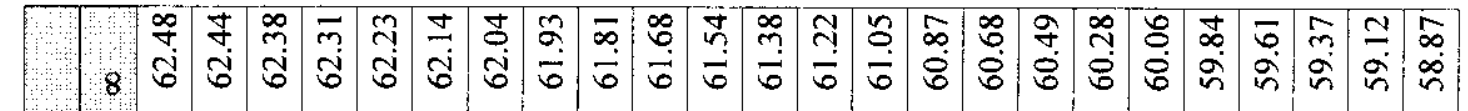

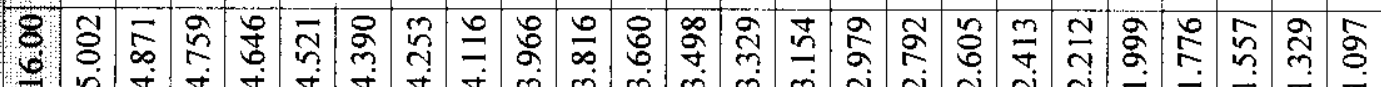

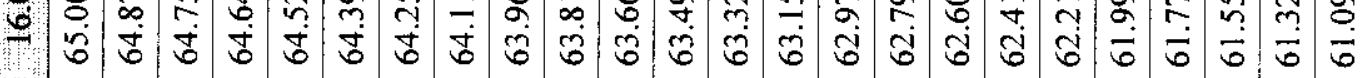

8. त

ठำ ২)

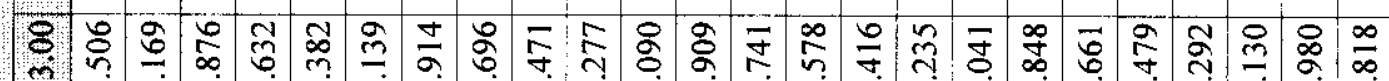

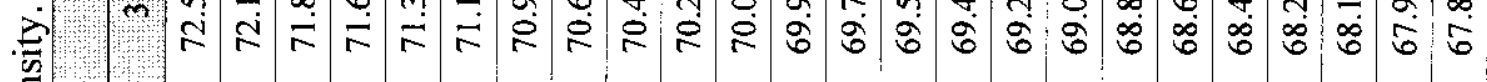

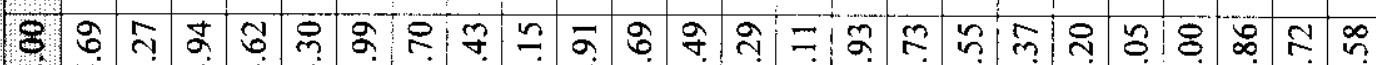

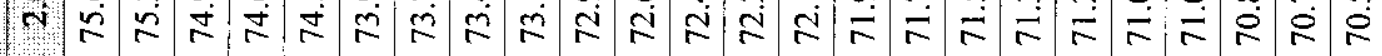

S =

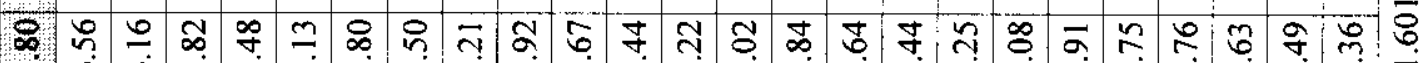

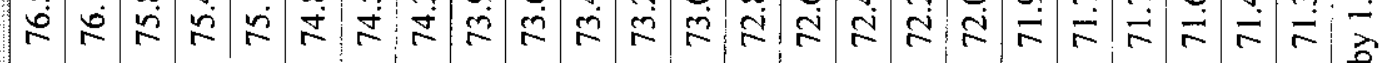

5 : :

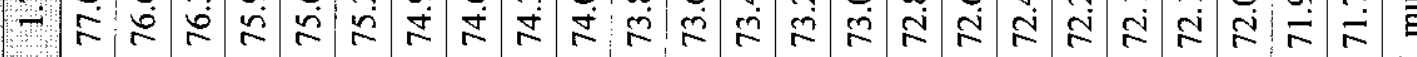

$\dot{\hat{N}}$

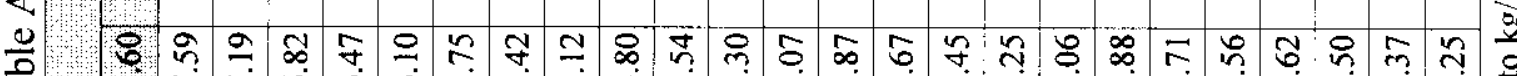
告

И)

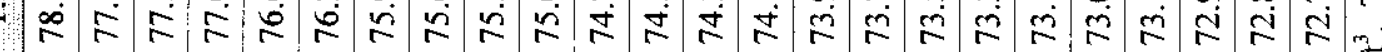

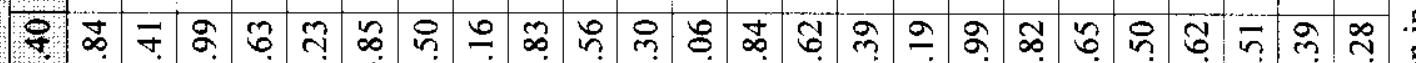

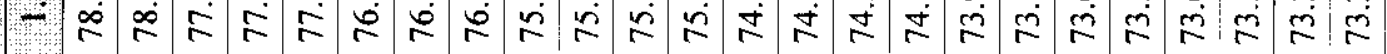

응 -

ह) 


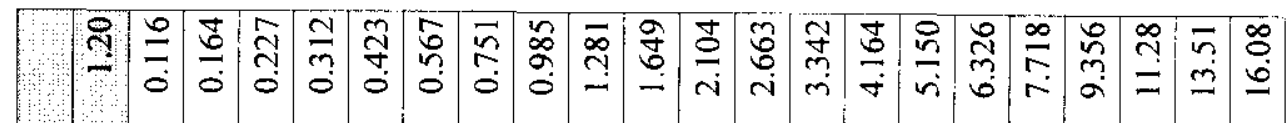

$$
\begin{aligned}
& \text { 를 }
\end{aligned}
$$

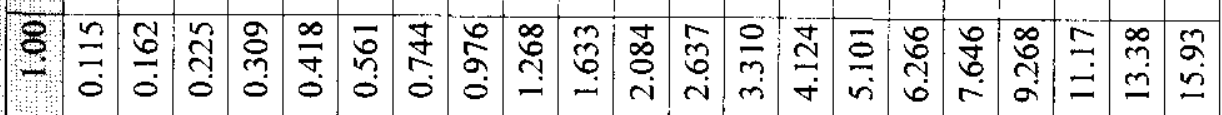

$$
\begin{aligned}
& \text { \& }
\end{aligned}
$$

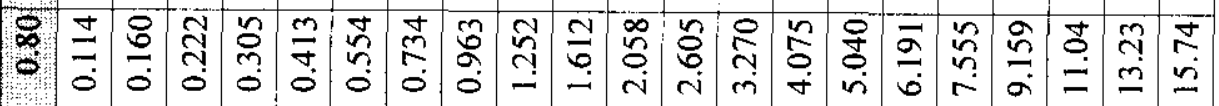

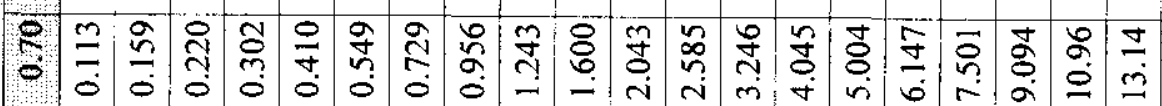

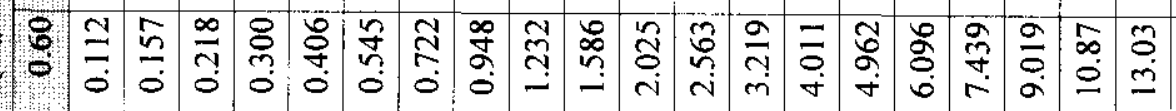

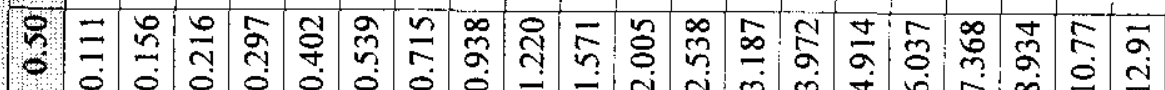

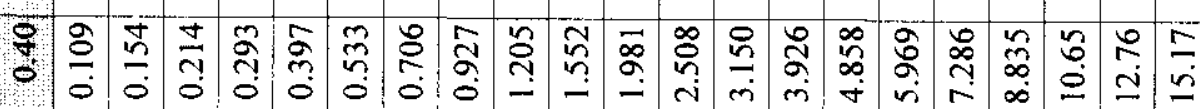

ऽ)

đิ

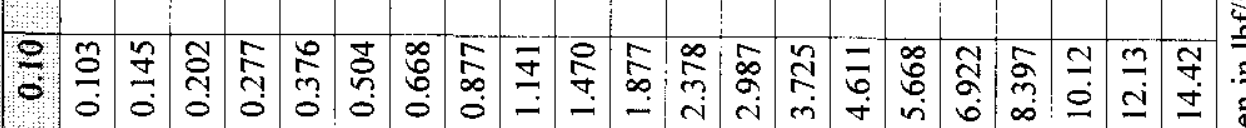

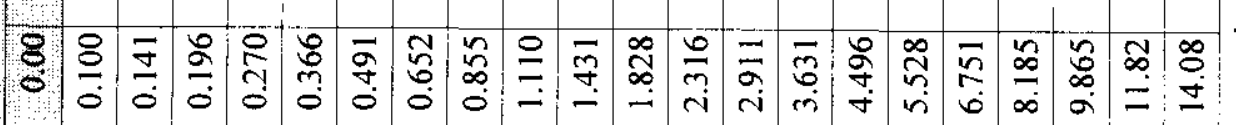




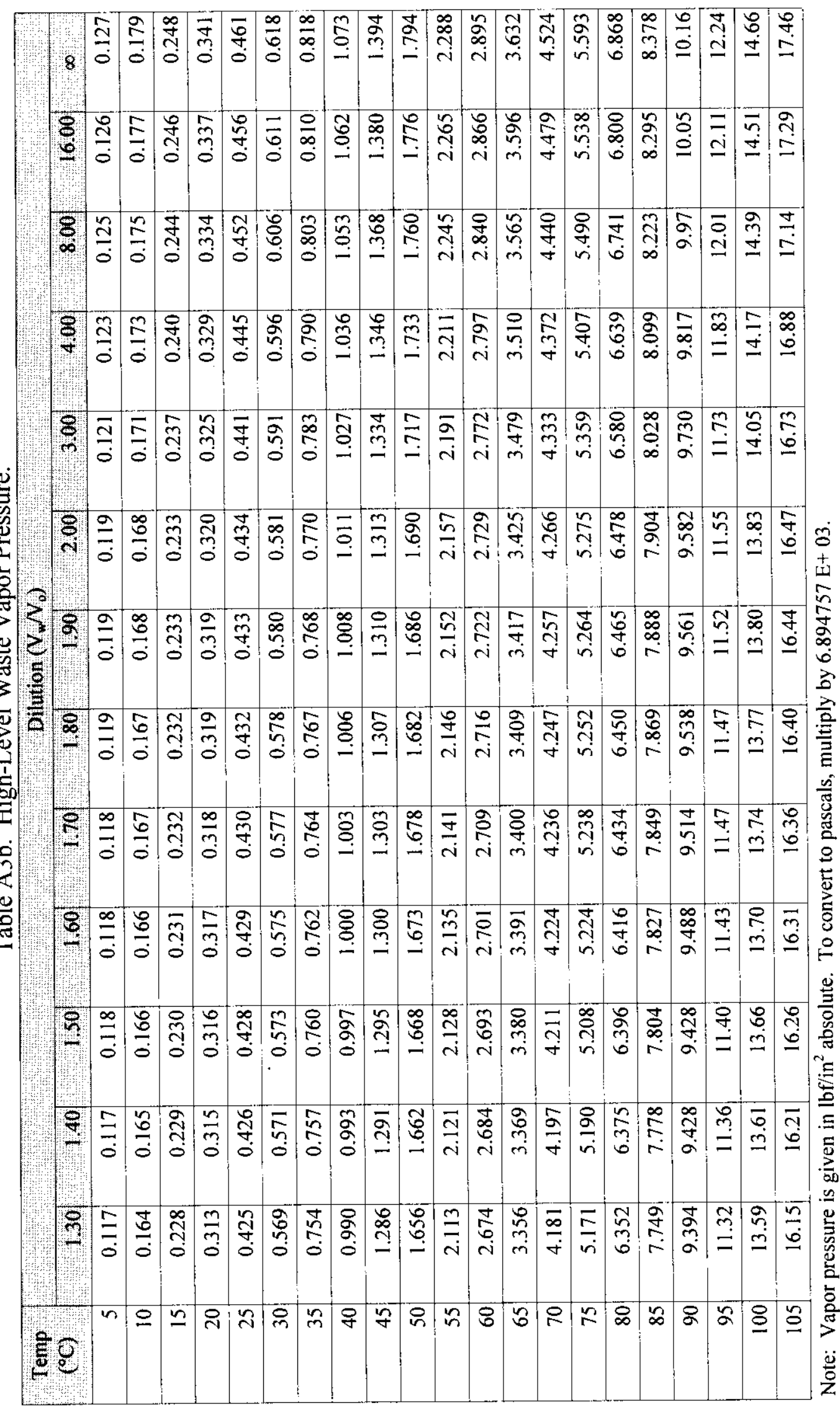


This page cannot be converted.

Please view the native document

for the original page. 


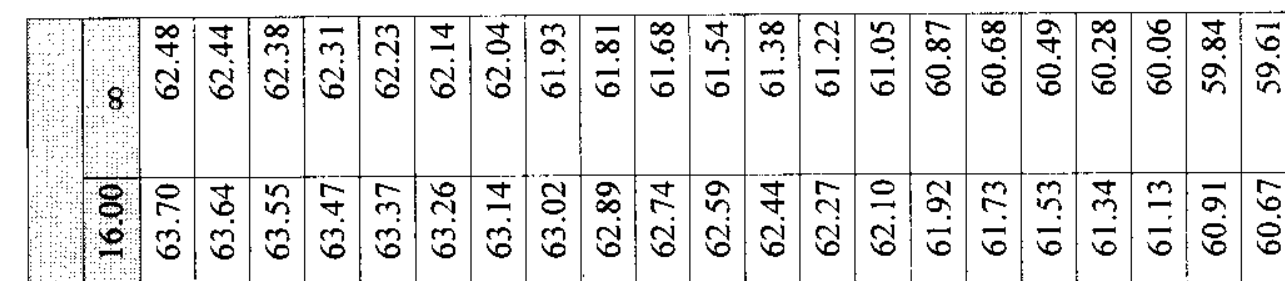

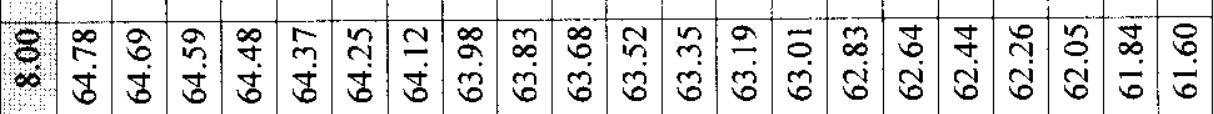

8 幽 भा

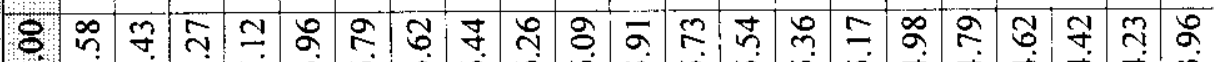

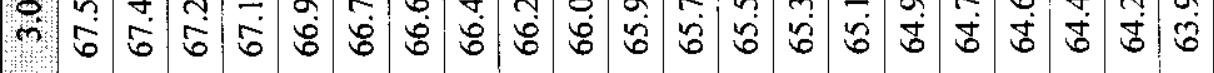

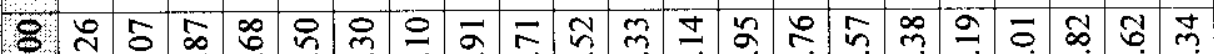
त1

웅

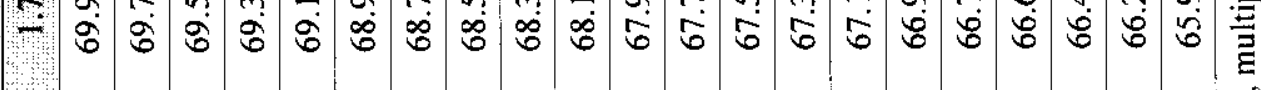

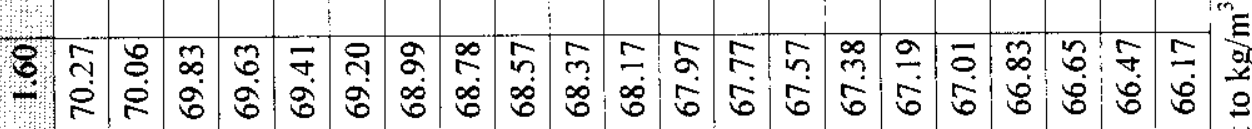

B.

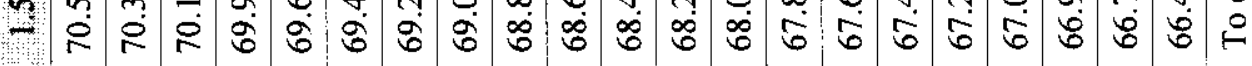

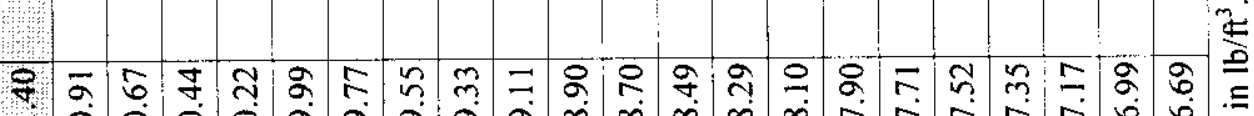

-

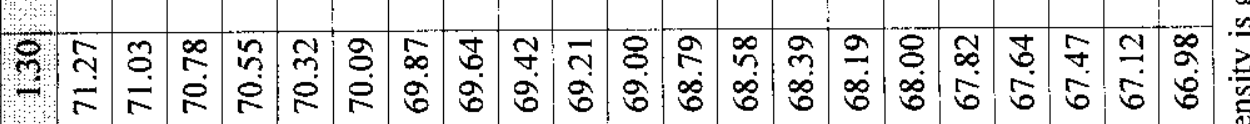

हैढ्: 

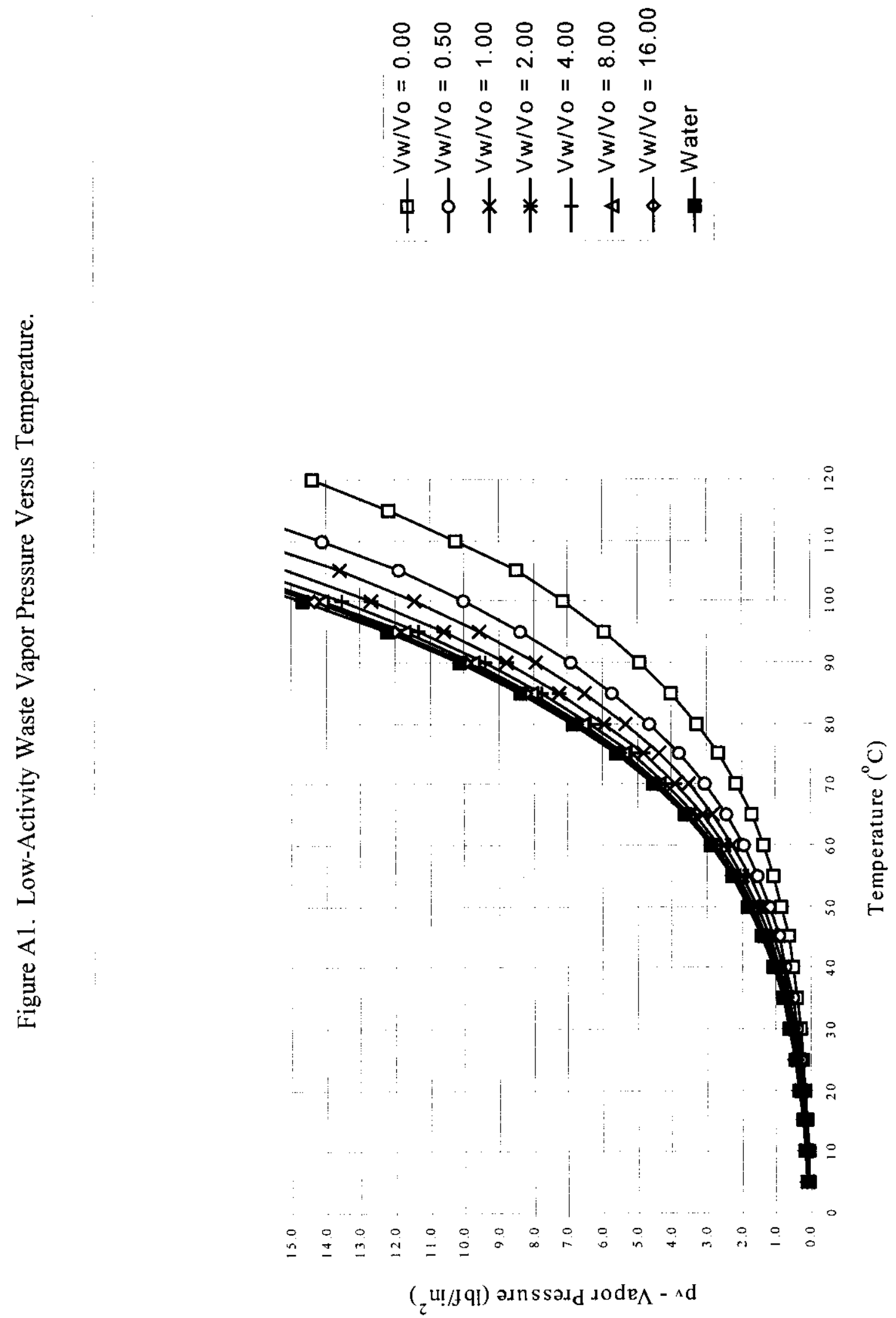

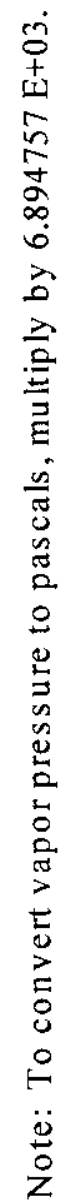


HNF-5585 REV 0

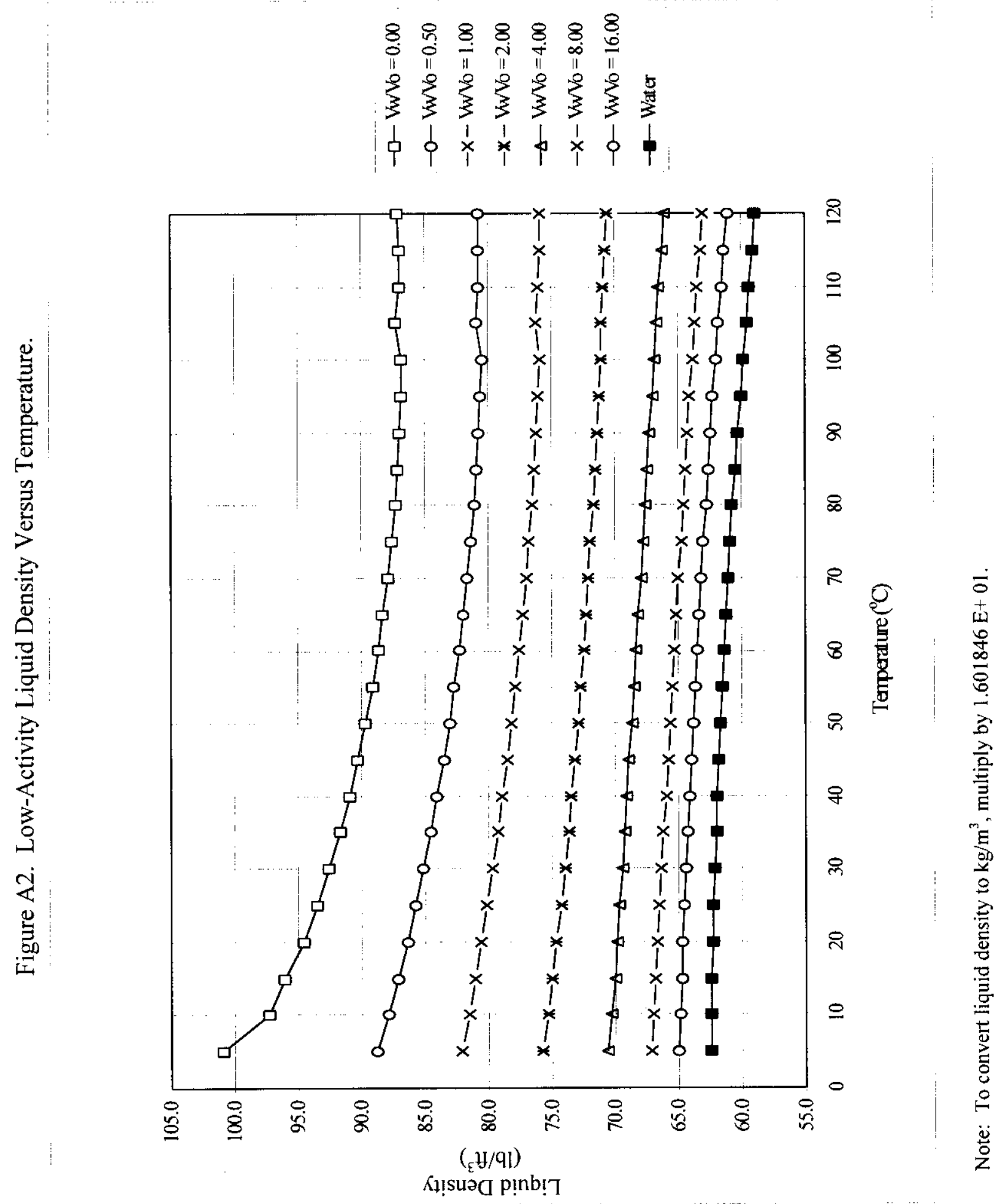


HNF-5585 REV 0
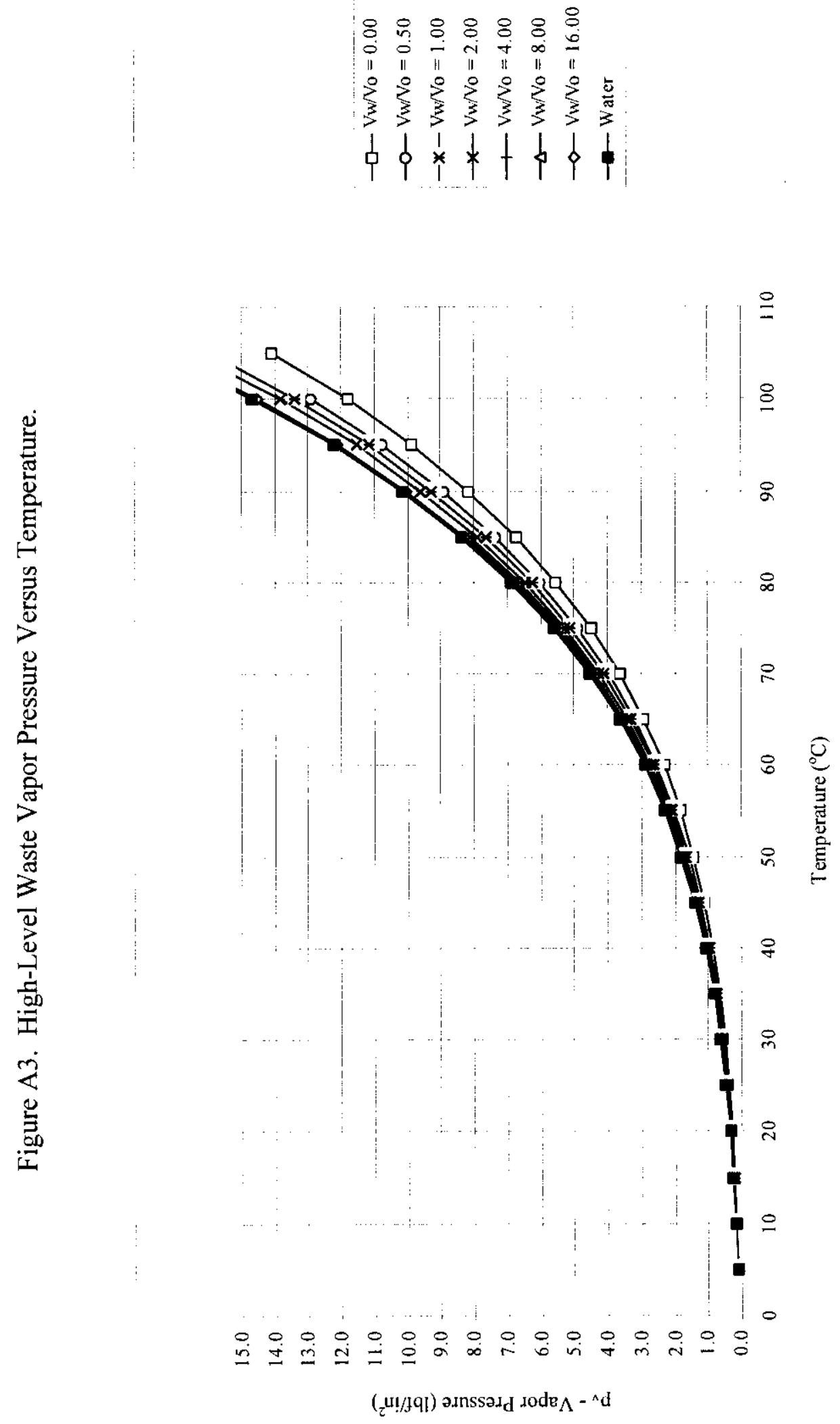
HNF-5585 REV 0

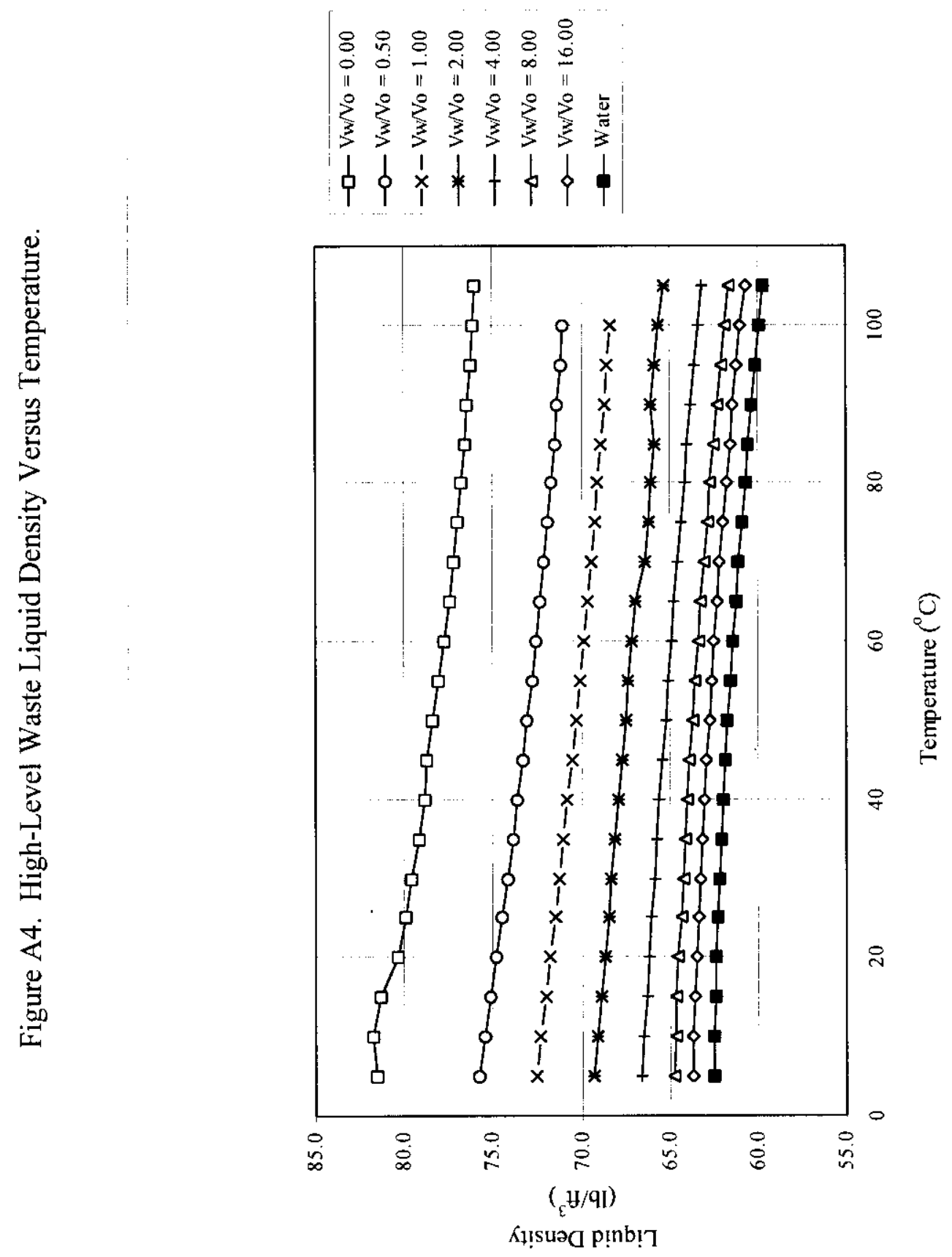

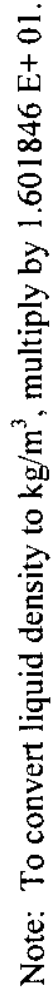


HNF-5585 REV 0

\section{DISTRIBUTION}

\section{Onsite}

U.S. Department of Energy

Richland Operations Office

DOE Public Reading Room

$\mathrm{H} 2-53$

1

Pacific Northwest National Laboratory

Hanford Technical Library

P8-55

Lockheed Martin Services, Inc.

Central Files

B1-07

Document Processing Center

A3-94

Distr-1 
HNF-5585 REV 0

This page intentionally left blank.

Distr-2 


\begin{tabular}{|c|c|c|c|c|c|}
\hline \multicolumn{6}{|c|}{ DISTRIBUTION SHEET } \\
\hline \multirow{2}{*}{$\begin{array}{l}\text { To: } \\
\text { Distribution }\end{array}$} & \multirow{2}{*}{\multicolumn{3}{|c|}{$\begin{array}{l}\text { From: } \\
\text { Retrieval Engineering }\end{array}$}} & \multicolumn{2}{|c|}{ Page 1 of 1} \\
\hline & & & & \multicolumn{2}{|c|}{ Date $\operatorname{March} 22,2000$} \\
\hline \multicolumn{4}{|l|}{ Project Title/Work Order: } & \multicolumn{2}{|c|}{ EDT No. 627143} \\
\hline \multicolumn{4}{|c|}{$\begin{array}{l}\text { RPP-5585, Rev. } 0 \\
\text { Net Positive Suction Head Available }\end{array}$} & \multicolumn{2}{|c|}{ ECN No. --- } \\
\hline Name & MSIN & $\begin{array}{c}\text { Text } \\
\text { With All } \\
\text { Attach. }\end{array}$ & $\begin{array}{l}\text { Text } \\
\text { Only }\end{array}$ & $\begin{array}{c}\text { Attach./ } \\
\text { Appendix } \\
\text { Only }\end{array}$ & $\begin{array}{l}\text { EDT/ECN } \\
\text { Only }\end{array}$ \\
\hline R. R. Bafus & R3-73 & $\mathrm{X}$ & & & \\
\hline A. F. Choho & R3-73 & & & & $\mathrm{X}$ \\
\hline T.J. Conrads & $\mathrm{R} 3-73$ & $\mathrm{X}$ & & & \\
\hline G. C. DeWeese & R3-73 & $\mathrm{X}$ & & & \\
\hline D. P. Fassett & R3-73 & $\mathrm{X}$ & & & \\
\hline C. E. Graves & R3-73 & $\mathrm{X}$ & & & \\
\hline C. E. Grenard & $\mathrm{R} 3-73$ & $\mathrm{X}$ & & & \\
\hline G. A. Leshikar & S0-08 & $\mathrm{X}$ & & & \\
\hline T. H. May & $\mathrm{R} 2-11$ & $\mathrm{X}$ & & & \\
\hline R. L. Neavill (Project Files) & R3-73 & $\mathrm{X}$ & & & \\
\hline J. H. Rasmussen & $\mathrm{R} 2-12$ & $\mathrm{X}$ & & & \\
\hline C. P. Shaw & R3-74 & $\mathrm{X}$ & & & \\
\hline E. A. Smith & G3-15 & $X$ & & & \\
\hline DIMC & $\mathrm{H} 7-15$ & $\mathrm{X}$ & & & \\
\hline
\end{tabular}

